\title{
COMUNICAÇÃO
}

\section{EFEITO DE CONCENTRAÇÕES DE GLICINA E INOSITOL NO CULTIVO IN VITRO DE DUAS FRUTÍFERAS DE CLIMA TEMPERADO}

\author{
Effect of glycine and inositol concentrations on two in vitro cultivated temperate fruit trees
}

\author{
Fabíola Villa ${ }^{1}$, Moacir Pasqual², Leila Aparecida Salles Pio ${ }^{1}$, \\ Franscinely Aparecida Assis ${ }^{3}$, Danielle Zampiere Arce Zárraga ${ }^{4}$
}

\begin{abstract}
RESUMO
A fim de aprimorar técnicas de cultivo in vitro de duas frutíferas de clima temperado (amoreira-preta cv. Tupy e porta-enxerto de videira cv. Kobber 5BB), testaram-se diferentes concentrações de glicina e inositol, adicionadas ao meio de cultura. Para plântula de amoreirapreta, o meio foi constituído do meio básico MS, acrescido de $30 \mathrm{~g} \mathrm{~L}^{-1}$ de sacarose e $7 \mathrm{~g} \mathrm{~L}^{-1}$ de ágar, e o $\mathrm{pH}$ ajustado para 5,8 antes da autoclavagem a $121^{\circ} \mathrm{C}$ e 1 atm por 20 minutos; e do meio básico DSD1 para porta-enxerto de videira cv. Kobber 5BB, acrescido de $20 \mathrm{~g} \mathrm{~L}^{-1}$ de sacarose e $7 \mathrm{~g} \mathrm{~L}^{-1}$ de ágar, e o pH ajustado para 6,4. O experimento com amoreira-preta consistiu de 5 diferentes concentrações de glicina (0; 1,0; 2,0; 4,0 e 8,0 $\left.\mathrm{mg} \mathrm{L}^{-1}\right), 5$ de inositol $\left(0 ; 50 ; 100 ; 200\right.$ e $\left.400 \mathrm{mg} \mathrm{L}^{-1}\right)$ e suas combinações. O experimento com videira consistiu de 4 diferentes concentrações de glicina $\left(0 ; 1,0 ; 2,0\right.$ e 4,0 $\left.\mathrm{mg} \mathrm{L}^{-1}\right), 4$ de inositol $\left(0 ; 10 ; 20\right.$ e $\left.40 \mathrm{mg} \mathrm{L}^{-1}\right)$ e suas combinações. Segmentos nodais, oriundos de plântulas preestabelecidas in vitro foram excisados e introduzidos em tubos de ensaio contendo $15 \mathrm{~mL}$ dos meios de cultura. Posteriormente, os tubos de ensaio foram transferidos para sala de crescimento a $25 \pm 2^{\circ} \mathrm{C}$, irradiância de $32 \mathrm{mmol} \mathrm{m} \mathrm{m}^{-2} \mathrm{~s}^{-1}$ e fotoperíodo de 16 horas. $\mathrm{O}$ delineamento experimental utilizado foi o inteiramente casualisado, utilizando-se de doze plântulas por tratamento. Após 70 dias de cultivo in vitro, melhores resultados para a amoreira-preta cv. Tupy foram obtidos com concentração de glicina até a recomendada no meio de cultura MS (2,0 $\left.\mathrm{mg} \mathrm{L}^{-1}\right)$ e 4 vezes o valor de inositol. Para o porta-enxerto de videira, melhores resultados foram obtidos na ausência e/ou com baixas concentrações de glicina e concentração de inositol igual ou superior à recomendada no meio de cultura DSD1.
\end{abstract}

Termos para Indexação: Vitamina, aminoácido, MS, DSD1, amoreira-preta, videira.

\section{ABSTRACT}

Aiming to improve the in vitro cultivation techniques of two temperate fruit i.e. blackberry cv. Tupy and grapevine rootstock cv. Kobber 5BB, different glycine and inositol concentrations in the culture medium were tested. The culture medium was constituted of MS basal medium, added of $30 \mathrm{~g} \mathrm{~L}^{-1}$ sucrose and $7 \mathrm{~g} \mathrm{~L}^{-1}$ agar, and the $\mathrm{pH}$ adjusted to 5.8 before the sterilization of $121^{\circ} \mathrm{C}$ and 1 atm for 20 minutes, and DSD1 basal medium for grapevine rootstock cv. Kobber 5BB, added of $20 \mathrm{~g} \mathrm{~L}^{-1}$ sucrose and $7 \mathrm{~g} \mathrm{~L}^{-1}$ agar, and the $\mathrm{pH}$ adjusted to 6.4 . The work with blackberry consisted of 5 different concentrations of glycine $\left(0 ; 1.0 ; 2.0 ; 4.0\right.$ and $\left.8.0 \mathrm{mg} \mathrm{L}^{-1}\right), 5$ of inositol $(0 ; 500 ; 100 ; 200$ and $\left.400 \mathrm{mg} \mathrm{L}^{-1}\right)$ and its combinations. The work with grapevine composed of 4 different concentrations of glycine $\left(0 ; 1.0 ; 2.0\right.$ and $\left.4.0 \mathrm{mg} \mathrm{L}^{-1}\right)$, 4 of inositol $\left(0 ; 10 ; 20\right.$ and $\left.40 \mathrm{mg} \mathrm{L}^{-1}\right)$, and its combinations. Nodal segments from in vitro plants was excised and introduced into test tubes containing $15 \mathrm{~mL}$ of culture medium. After that, the culture tubes were transferred in a growth room to $25 \pm 2^{\circ} \mathrm{C}$, irradiance of $32 \mathrm{~mol} \mathrm{~m}^{-2} \cdot \mathrm{s}^{-1}$ and photoperiod of 16 hours. The experiments were settled in a completely randomized design, using twelve explants per treatment. After 70 days of in vitro cultivation, better results for the blackberry cv. Tupy were obtained with glycine concentration as recommended in the MS culture medium $\left(2 \mathrm{mg} \mathrm{L}^{-1}\right)$ and 4 fold of the inositol value. For the grapevine rootstock, better results were obtained in the absence and/or with low glycine concentrations and the same or higher inositol concentration as recommended in the DSD1 culture medium.

Index terms: Vitamin, aminoacid, MS, DSD1, blackberry, grapevine.

\section{(Recebido em 27 de abril de 2006 e aprovado em 27 de março de 2007)}

A fruticultura de clima temperado apresenta grande importância no contexto da produção mundial de frutas. Algumas delas produzidas em maior volume em todo o mundo, tais como a macieira e a videira, são de espécies pertencentes a esta classe (CHALFUN et al., 1998).
No Brasil, a amoreira-preta vem sendo cultivada por pequenos produtores, objetivando a exportação dos frutos. O Rio Grande do Sul é o principal produtor brasileiro, onde a cultivar Tupy responde por $70 \%$ da área cultivada (ANTUNES \& RASEIRA, 2004). O Sul de Minas Gerais

\footnotetext{
Doutoranda em Fitotecnia - Departamento de Agricultura/DAG - Universidade Federal de Lavras/UFLA - Cx. P. 3037 - $37200-000$ - Lavras, MG fvilla2003@libero.it; leilapio@ufla.br

${ }^{2}$ Doutor, Professor Titular - Departamento de Agricultura/DAG - Universidade Federal de Lavras/UFLA - Cx. P. 3037 - $37200-000$ - Lavras, MG mpasqual@ufla.br

${ }^{3}$ Graduação em Agronomia - Departamento de Agricultura/DAG - Universidade Federal de Lavras/UFLA - Cx. P. 3037 - $37200-000$ - Lavras, MG franscinely.agronomia@ufla.br

${ }^{4}$ Graduação em Ciências Biológicas - UNILAVRAS - Campus Universitário - 37200-000 - Lavras, MG - danitucha@hotmail.com
} 
tem apresentado elevado potencial para esta pequena fruta, destacando-se o município de Caldas.

A propagação da amoreira-preta faz-se através de estacas de raízes (CALDWELL, 1984), brotos (rebentos) e estacas herbáceas (ANTUNES, 1999). A videira é uma espécie frutífera propagada por via vegetativa. O cultivo in vitro pode ser utilizado como um processo alternativo, visando, por meio de suas técnicas, a obtenção de um grande número de mudas, geneticamente uniformes, livres de vírus e em curto espaço de tempo (PEIXOTO \& PASQUAL, 1996; SKIRVIN et al., 1981).

Um dos objetivos da micropropagação é a maximização da multiplicação de gemas. Muita atenção para sua obtenção tem sido dada à manipulação de substâncias de crescimento no meio de cultura (LEE \& KO, 1984). Vários meios de cultura têm sido testados e um meio específico é identificado pela composição de sais minerais, enquanto as vitaminas, os reguladores vegetais e outros suplementos orgânicos variam em concentração.

A suplementação de um meio de cultura pode ser realizada pela inclusão de uma proteína hidrolisada. Qualquer efeito benéfico pode ser avaliado pela substituição dessa proteína por uma mistura de aminoácidos. Os aminoácidos têm importância na amplificação das respostas morfogenéticas, proporcionando maior crescimento e facilitando a diferenciação no sentido da regeneração (PASQUAL, 2001).

O crescimento e a morfogenia de plântulas micropropagadas podem ser melhorados com a adição de vitaminas ao meio de cultura. As exigências das células vegetais em vitaminas estão associadas ao tipo de cultura e à espécie (GEORGE, 1993). Gonzáles et al. (2000) observaram melhor estabelecimento in vitro de mirtilo cv. Berkeley a partir de segmentos nodais, utilizando meio WPM acrescido de vitaminas do MS. Em 4 genótipos de videira estudados verificaram-se melhores resultados em meio modificado, com a diminuição de sais e vitaminas do meio de cultivo MS (ZLENKO et al., 1995).

Objetivou-se neste trabalho avaliar os efeitos de diferentes concentrações de glicina e inositol, no cultivo in vitro de amoreira-preta cv. Tupy e do porta-enxerto de videira cv. Kobber 5BB.

Segmentos nodais de amoreira-preta (Rubus sp. cv. Tupy) e do porta-enxerto de videira (Vitis spp. cv. Kobber 5BB), com $2 \mathrm{~cm}$ de comprimento, oriundos de plântulas preestabelecidas in vitro foram excisados e introduzidos em tubo de ensaio contendo $15 \mathrm{~mL}$ de meio de cultura MS (MURASHIGE \& SKOOG, 1962) e DSD1 (SILVA \& DOAZAN, 1995), respectivamente. O primeiro meio de cultura foi acrescido de $1,0 \mathrm{mg} \mathrm{L}^{-1}$ de benzilaminopurina
(BAP), $30 \mathrm{~g} \mathrm{~L}^{-1}$ de sacarose e $7 \mathrm{~g} \mathrm{~L}^{-1}$ de ágar, e o $\mathrm{pH}$ foi ajustado para 5,8 , antes da autoclavagem a $121^{\circ} \mathrm{C}$ e $1 \mathrm{~atm}$ por 20 minutos. O segundo meio de cultura foi acrescido de $20 \mathrm{~g} \mathrm{~L}^{-1}$ de sacarose e $7 \mathrm{~g} \mathrm{~L}^{-1}$ de ágar, e o $\mathrm{pH}$ foi ajustado para 6,4, antes da autoclavagem. Posteriormente, os tubos de ensaio contendo os explantes foram transferidos para a sala de crescimento, onde as condições de cultivo foram mantidas a $25 \pm 2^{\circ} \mathrm{C}$, irradiância de $32 \mathrm{~m} \cdot \mathrm{mol} \cdot \mathrm{m}^{-2} \cdot \mathrm{s}^{-1} \mathrm{e}$ fotoperíodo de 16 horas.

$\mathrm{O}$ experimento com amoreira-preta (cv. Tupy) consistiu de 5 diferentes concentrações de glicina $(0 ; 1,0$; 2,0; 4,0 e 8,0 $\left.\mathrm{mg} \mathrm{L}^{-1}\right)$ e 5 de inositol $(0,50,100,200$ e $400 \mathrm{mg}$ $\left.\mathrm{L}^{-1}\right)$, em todas as combinações possíveis. $\mathrm{O}$ experimento com porta-enxerto de videira (cv. Kobber 5BB) consistiu de 4 diferentes concentrações de glicina $(0 ; 1,0 ; 2,0$ e 4,0 $\left.\mathrm{mg} \mathrm{L}^{-1}\right)$ e 4 de inositol $\left(0,10,20\right.$ e $\left.40 \mathrm{mg} \mathrm{L}^{-1}\right)$, retiradas do meio MS, em todas as combinações possíveis.

Ao final de 70 dias de cultivo in vitro, foram avaliados número de folhas, peso da matéria fresca da parte aérea, comprimento da parte aérea, número de raízes e peso fresco de calos para as duas frutíferas estudadas e somente número de brotos para a amoreira-preta e comprimento da maior raiz para o porta-enxerto de videira.

Os dados foram analisados através do software Sisvar (FERREIRA, 2000), utilizando regressão polinomial para concentrações de glicina e inositol. O delineamento experimental utilizado foi o inteiramente casualisado, com quatro repetições constituídas de três explantes.

As concentrações de inositol e glicina incorporadas ao meio de cultura MS influenciaram no número de folhas de amoreira-preta. Com o aumento nas concentrações de inositol, verificou-se um aumento no número de folhas, sendo que o maior número foi observado com $400 \mathrm{mg} \mathrm{L}^{-1}$, na ausência de glicina (Figura 1A).

Foi observada interação significativa para glicina e inositol separadamente em relação ao número de folhas do porta-enxerto de videira (Figuras 1B e 1C). Esses resultados divergem daqueles verificados para número de folhas de amoreira-preta. Para o porta-enxerto de videira, pode-se observar que a quantidade de folhas aumenta gradativamente até o ponto de máxima $(11,69)$ para $1,0 \mathrm{mg}$ $\mathrm{L}^{-1}$ de glicina e diminui até o ponto de máxima $(12,54)$ para $10 \mathrm{mg} \mathrm{L}^{-1}$ de inositol.

Na Figura 1B observa-se que o aumento gradativo nas concentrações de inositol (retiradas do meio de cultivo MS) reduziu a emissão de novas folhas, corroborando assim com Silva (2003), que estudando o crescimento in vitro de um híbrido de orquídea, verificou uma redução no número de folhas emitidas em meio Knudson, com o aumento das concentrações de vitaminas do meio MS. 


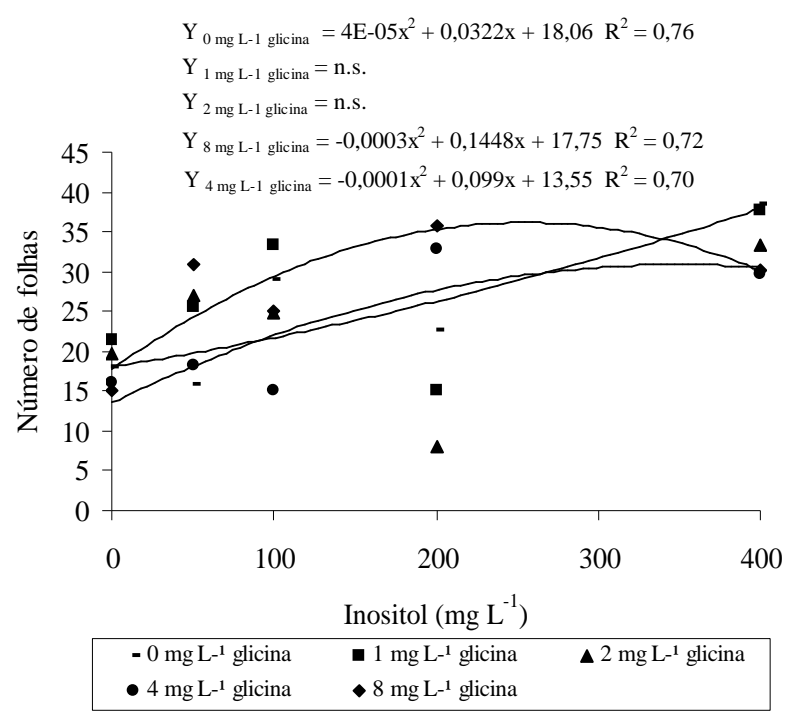

Figura 1A - Número de folhas de amoreira-preta, cv. Tupy, cultivada em diferentes concentrações de inositol e glicina.

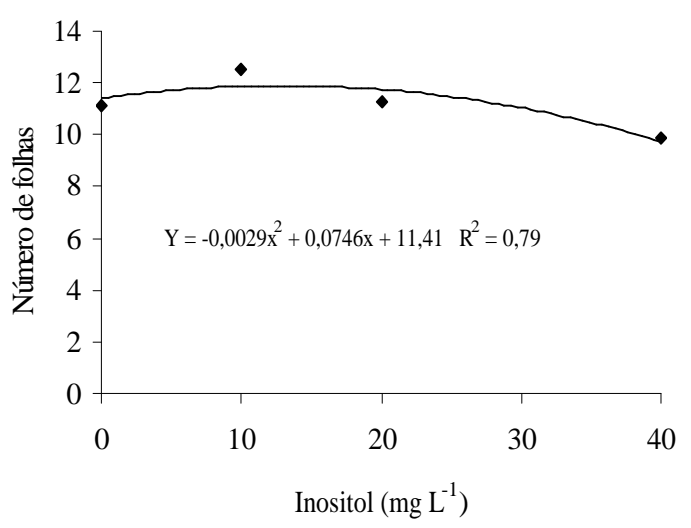

Figura 1B - Número de folhas do porta-enxerto de videira cv. Kobber 5BB', cultivado em diferentes concentrações de inositol.

O inositol influenciou como catalisador metabólico no crescimento de órgãos, confirmando sua função de estimular o crescimento geral da plântula (GEORGE, 1993). Pode-se inferir que o inositol retirado do meio MS, adicionado ao meio de cultura DSD1, não é necessário para promover número de folhas do porta-enxerto de videira.

Gonzáles et al. (2000) observaram melhor estabelecimento in vitro de mirtilo cv. Berkeley a partir de segmentos nodais, utilizando meio WPM acrescido de vitaminas do MS. Em 4 genótipos de videira estudados verificou-se melhores resultados em meio modificado, com a diminuição de sais e vitaminas do meio de cultivo MS (ZLENKO et al., 1995).

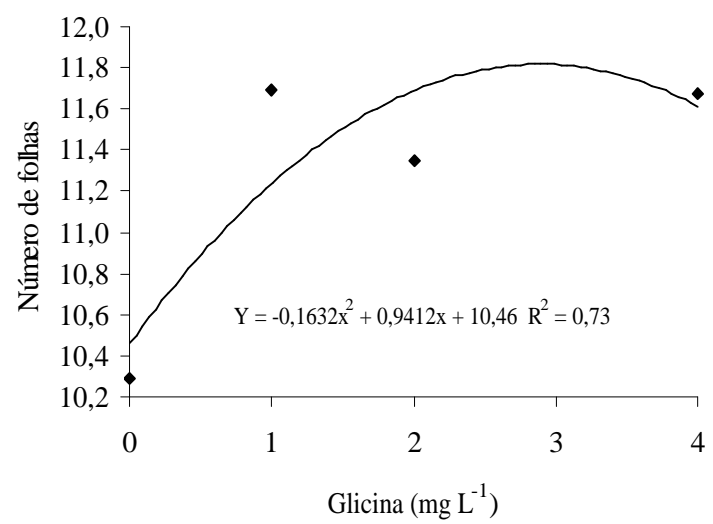

Figura $1 \mathrm{C}$ - Número de folhas do porta-enxerto de videira cv. Kobber 5BB', cultivado em diferentes concentrações de glicina.

Observa-se na Figura 2 uma interação significativa para número de brotos de amoreira-preta, em 2,0 e 8,0 mg L${ }^{1}$ de glicina, onde maior número foi verificado com $200 \mathrm{mg}$ $\mathrm{L}^{-1}$ de inositol associado a $2,0 \mathrm{mg} \mathrm{L}^{-1}$ de glicina. Concentrações superiores a $200 \mathrm{mg} \mathrm{L}^{-1}$ de inositol promoveram o crescimento do explante, função principal das vitaminas (GEORGE, 1993).

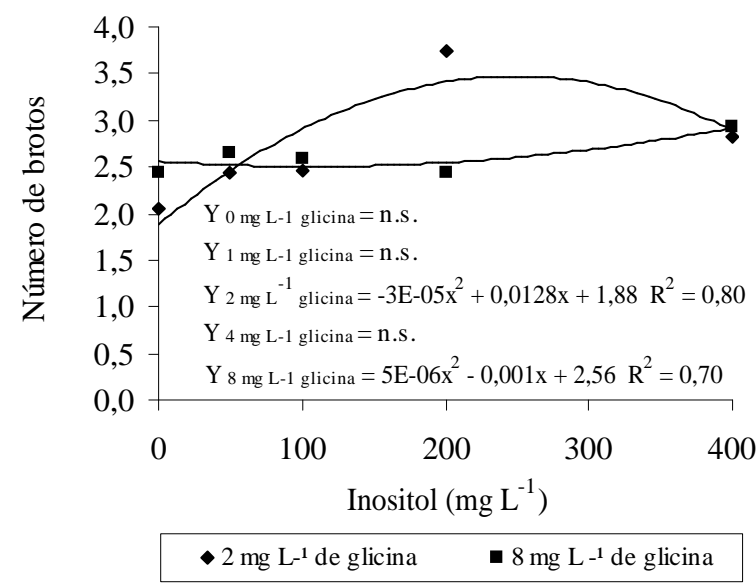

Figura 2 - Número de brotos de amoreira-preta, cv. Tupy, cultivada em diferentes concentrações de inositol e glicina.

Na Figura 3A e 3B pode-se verificar a interação significativa para o peso da matéria fresca da parte aérea das duas frutíferas estudadas. Maior peso da matéria fresca da parte aérea de amoreira-preta e porta-enxerto de videira foi verificado com 400 e $20 \mathrm{mg} \mathrm{L}^{-1}$ de inositol, respectivamente, com $1,0 \mathrm{mg} \mathrm{L}^{-1}$ de glicina e na sua ausência. Evidencia-se assim que, para promover peso da matéria fresca dessas duas frutíferas estudadas, a glicina do meio MS é inibitória e o inositol é benéfico. 
VILLA, F. et al.

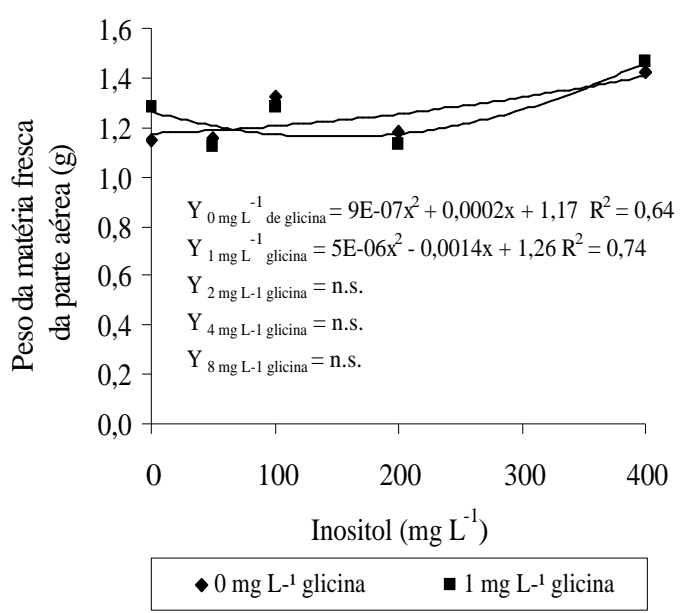

Figura 3A - Peso da matéria fresca da parte aérea de amoreirapreta cv. Tupy, cultivada em diferentes concentrações de glicina e inositol.

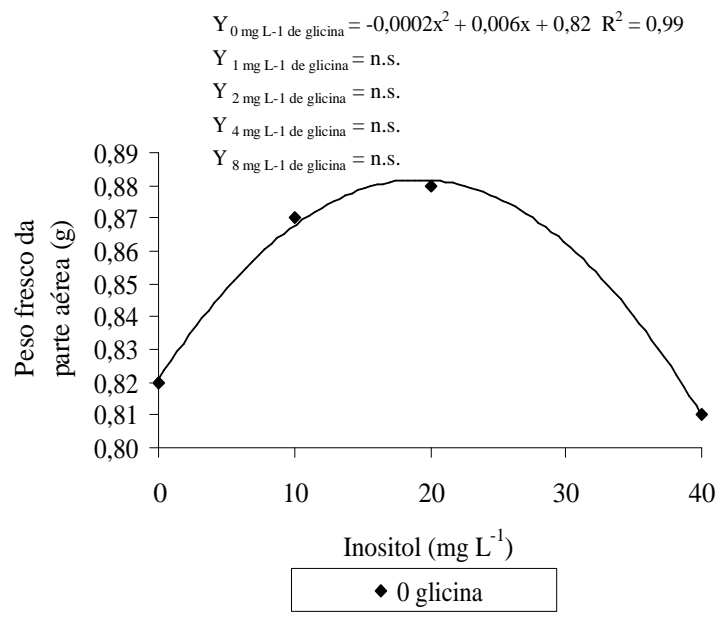

Figura 3B - Peso da matéria fresca da parte aérea do portaenxerto de videira cv. Kobber 5BB', cultivado em diferentes concentrações de glicina e inositol.

Para a amoreira-preta foi observada influência negativa do inositol até $200 \mathrm{mg} \mathrm{L}^{-1}$ combinado com 2,0 mg $\mathrm{L}^{-1}$ de glicina (Figura 4A). Com o aumento nas concentrações de inositol associado a $8,0 \mathrm{mg} \mathrm{L}^{-1}$ de glicina, verificou-se um aumento de forma quadrática em seu comprimento.

As concentrações de 10 a $40 \mathrm{mg} \mathrm{L}^{-1}$ de inositol e 2 $\mathrm{mg} \mathrm{L}^{-1}$ de glicina adicionadas no meio DSD1 influenciaram positivamente de forma linear o comprimento do portaenxerto de videira (Figura 4B). O crescimento geral das plântulas é estimulado pelas vitaminas do meio de cultivo MS, influenciando assim como catalisadores metabólicos (GEORGE, 1993).

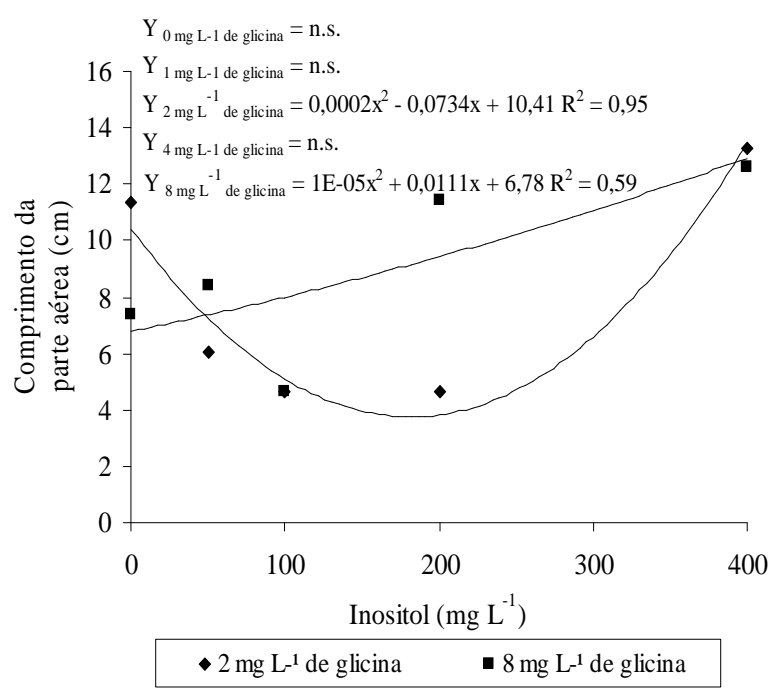

Figura 4A-Comprimento da parte aérea de amoreira-preta cv. Tupy, cultivada em diferentes concentrações de glicina e inositol.

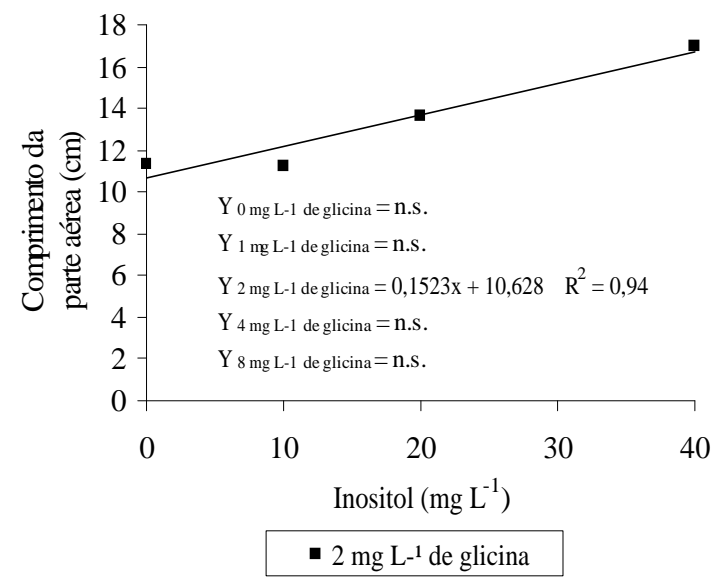

Figura 4B - Comprimento da parte aérea do porta-enxerto de videira cv. Kobber 5BB', cultivado em diferentes concentrações de glicina e inositol.

Pode-se observar na Figura 5 uma interação significativa para número de raízes da amoreira-preta na ausência e 1,0 $\mathrm{mg} \mathrm{L}^{-1}$ de glicina adicionada ao meio de cultivo. Maior número de raízes da amoreira-preta cv. Tupy foi verificado com $400 \mathrm{mg} \mathrm{L}^{-1}$ de inositol associado a 1,0 $\mathrm{mg} \mathrm{L}^{-1}$ de glicina, porém resultados semelhantes foram observados na ausência e com 1,0 $\mathrm{mg} \mathrm{L}^{-1}$ de glicina para essa cultivar.

De acordo com os resultados obtidos neste trabalho, pode-se inferir que não é necessária a utilização da glicina para obtenção de raízes nas plântulas. O número de raízes do porta-enxerto de videira cv. Kobber 5BB não 
foi significativo para as concentrações de inositol e glicina utilizadas.

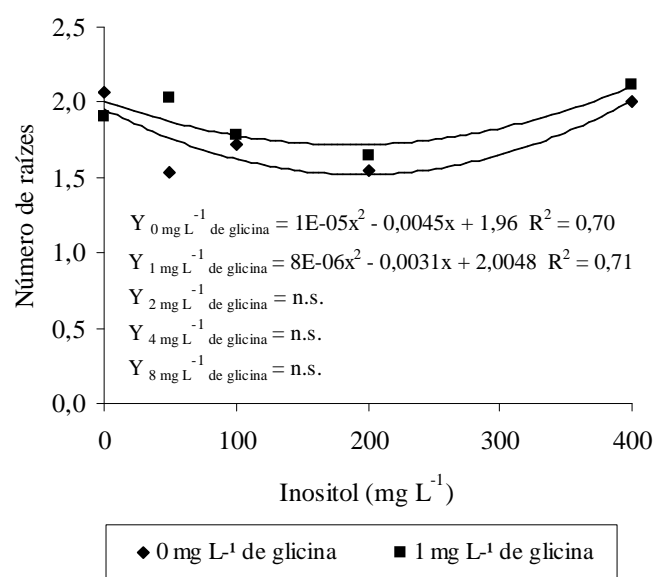

Figura 5 - Número de raízes de amoreira-preta, cv. Tupy, cultivada em diferentes concentrações de inositol e glicina.

Num substrato com deficiência de nutrientes, como é o caso do meio de cultura DSD1, aumentar o comprimento das raízes é uma maneira da plântula buscar os nutrientes necessários ao seu desenvolvimento, mesmo que isso implique em gasto de reservas.

As concentrações de inositol do meio MS influenciaram de maneira positiva o crescimento dessas raízes, até o ponto de máxima $(3,83 \mathrm{~cm}$ de comprimento e 23,6 $\mathrm{mg} \mathrm{L}^{-1}$ de inositol), evidenciando-se que, para promover o crescimento médio do sistema radicular da cv. Kobber 5BB, o inositol adicionado ao meio de cultivo DSD1 é benéfico (Figura 6).

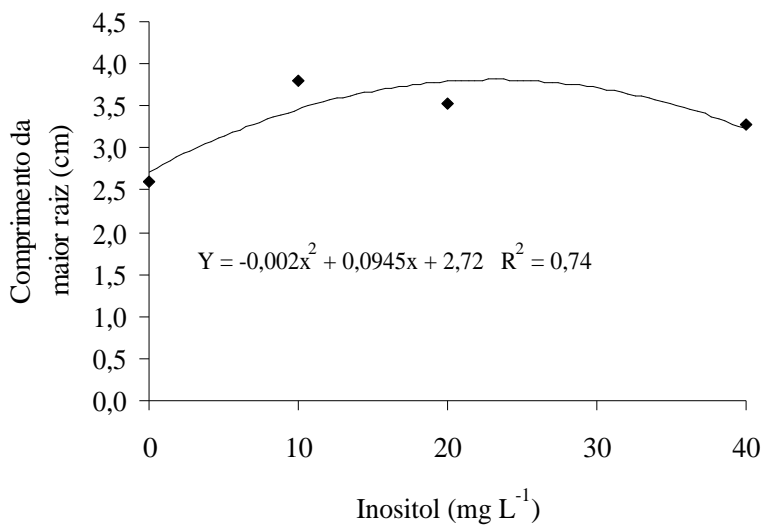

Figura 6 - Comprimento da maior raiz do porta-enxerto de videira cv. Kobber 5BB, cultivado em diferentes concentrações de inositol.
Pode-se observar nas Figuras 7A e 7B uma interação significativa para peso fresco de calos das frutíferas estudadas, sendo que, maior peso fresco de calos de amoreira-preta foi verificado com $400 \mathrm{mg} \mathrm{L}^{-1}$ de inositol associado a 2,0 $\mathrm{mg} \mathrm{L}^{-1}$ de glicina. Já para o porta-enxerto de videira, verificou-se que o inositol incrementou linearmente o peso da matéria fresca de calos com aumento de suas concentrações, na presença de $2,0 \mathrm{mg} \mathrm{L}^{-1}$ de glicina.

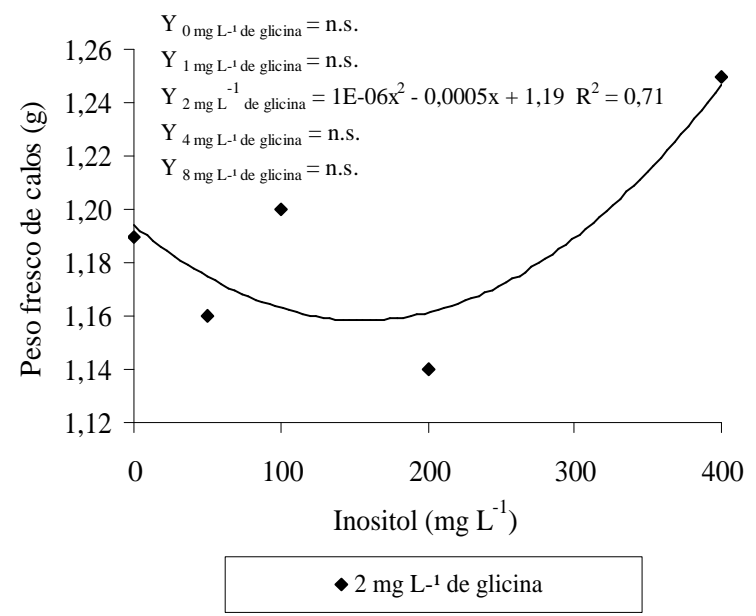

Figura 7A - Peso fresco de calos de amoreira-preta cv. Tupy, cultivada em diferentes concentrações de glicina e inositol.

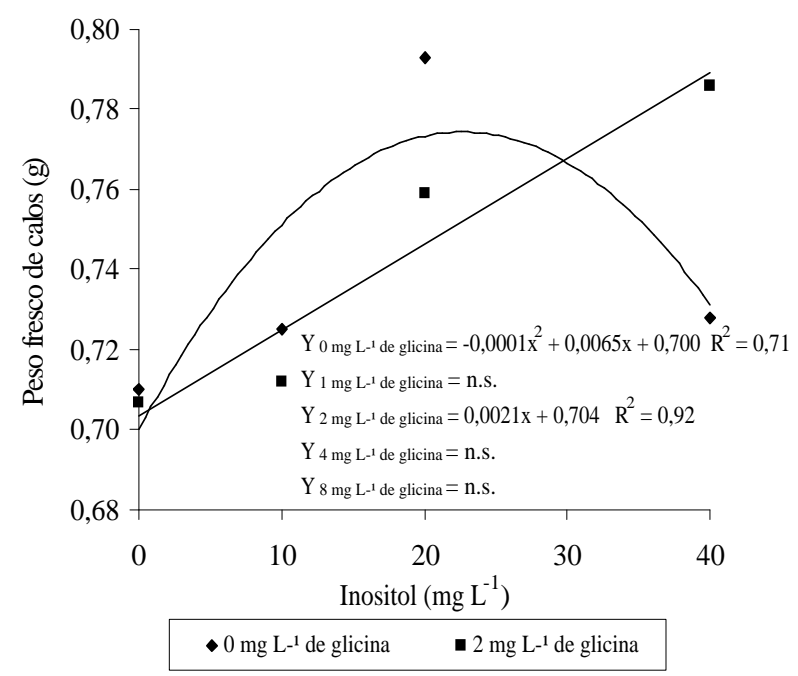

Figura 7B - Peso fresco de calos do porta-enxerto de videira cv. Kobber 5BB, cultivado em diferentes concentrações de glicina e inositol.

A formação de calos não é desejada nesse estudo, pois pode favorecer o surgimento de variação no genótipo. Provavelmente a glicina e o inositol do meio MS não sejam 
adequados para a micropropagação do porta-enxerto de videira cv. Kobber 5BB, pois proporcionou calos mesmo na ausência de ambos. O mesmo foi observado para a amoreira-preta, onde na ausência de inositol ocorreu a formação de calos na base das plântulas.

Kintzios et al. (2000, 2001) observaram em um estudo com folhas de rosa (Rosa hybrida) e de Capsicum annuиm que, na presença de $100 \mathrm{mg} \mathrm{L}^{-1}$ de inositol um maior crescimento de calos foi obtido. Esses verificaram também que a glicina a $0,1 \mathrm{mg} \mathrm{L}^{-1}$ foi a menos favorável para o mesmo crescimento e proliferação de embriões somáticos de $C$. апnиum.

Melhores resultados para micropropagação da amoreira-preta cv. Tupy são obtidos com concentração de glicina até a recomendada no meio de cultura MS (2,0 mg $\left.\mathrm{L}^{-1}\right)$ e $4 x$ (400 $\left.\mathrm{mg} \mathrm{L}^{-1}\right)$ o valor de inositol.

Para o porta-enxerto de videira, melhores resultados são obtidos na ausência e/ou com baixas concentrações de glicina e concentração de inositol igual ou superior à recomendada no meio de cultura DSD1 ( $\left.{ }^{3} 10 \mathrm{mg} \mathrm{L}^{-1}\right)$.

\section{REFERÊNCIAS BIBLIOGRÁFICAS}

ANTUNES, L. E. C. Aspectos fenológicos, propagação e conservação pós-colheita de frutas de amoreira-preta (Rubus spp) no sul de Minas Gerais. 1999. 129 p. Tese (Doutorado em Agronomia, Fitotecnia) - Universidade Federal de Lavras, Lavras, 1999.

ANTUNES, L. E. C.; RASEIRA, M. C. B. Aspectos técnicos da cultura da amora-preta. Pelotas: Embrapa Clima Temperado, 2004. (Documentos, 122).

CADWELL, J. D. Blackberry propagation. HortScience, Amsterdam, v. 19, n. 2, p. 193-195, 1984.

CHALFUN, N. N. J.; PASQUAL, M.; HOFFMANN, A. Fruticultura comercial: frutíferas de clima temperado. Lavras: UFLA-FAEPE, 1998. v. 7, 304 p.

FERREIRA, D. F. Análises estatísticas por meio do Sisvar para Windows versão 4.0. In: REUNIÃO ANUAL DA REGIÃO BRASILEIRA DA SOCIEDADE INTERNACIONAL DE BIOMETRIA, 45., 2000, São Carlos. Anais... São Carlos: UFSCar, 2000. p. 255-258.

GEORGE, E. F. (Ed.). Plant propagation by tissue culture: part 1: the technology. 2. ed. Edington: Exegetics, 1993. 574 p.

GONZALES, M. V.; LOPEZ, M.; VALDES, A. E.; ORDAS, R. J. Micropropagation of three berry fruit species using nodal segments from field-grown plants. Annals of Applied Biology, Cambridge, v. 137, p. 73-78, 2000.

KINTZIOS, S.; DROSSOPOULOS, J. B.; LYMPEROPOULOS, C. Effect of vitamins and inorganic micronutrients on callus growth and somatic embryogenesis from young mature leaves of rose (Rosa hybrida). Journal Plant of Nutrition, [S.1.], v. 23, n. 10, p. 1407-1420, 2000.

KINTZIOS, S.; DROSSOPOULOS, J. B.; LYMPEROPOULOS, C. Effect of vitamins and inorganic micronutrients on callus growth and somatic embryogenesis from leaves of chilli pepper. Plant Cell, Tissue and Organ Culture, Dordrecht, v. 27, p. 55-62, 2001.

LEE, H. J.; KO, K. C. Effects of culture media and plant hormones on shoot tip culture of Fuji apple cultivar (Malus domestica). Seoul National University Journal of Agricultural Sciences, Seoul, v. 9, n. 1, p. 67-77, 1984.

MURASHIGE, T.; SKOOG, F. A revised medium for rapid growth and bioassays with tobacco tissue cultures. Physiologia Plantarum, Copenhagen, v. 15, p. 473-497, 1962.

PASQUAL, M. Cultura de tecidos vegetais: tecnologia e aplicações: meios de cultura. Lavras: UFLA/FAEPE, 2001. 74 p.

PEIXOTO, P. H. P.; PASQUAL, M. Influência da origem dos explantes na multiplicação e no enraizamento in vitro de porta-enxertos de videira. Ciência e Agrotecnologia, Lavras, v. 20, n. 3, p. 293-300, 1996.

SILVA, A. L.; DOAZAN, J. P. Une méthode d'irradiation aux rayons gamma appliquée à des porte-greffes de Vigne in vitro. Journal International Science of Vigne et Vin, [S.1.], v. 29, p. 1-9, 1995.

SILVA, E. F. Multiplicação e crescimento in vitro de orquídea Brassiocattleya Pastoral x Laeliocattleya Amber Glow. 2003. 62 p. Dissertação (Mestrado em Fitotecnia) - Universidade Federal de Lavras, Lavras, 2003.

SKIRVIN, R. M.; CHU, M. C.; GOMEZ, E. In vitro propagation of Thornless Trailing Blackberries. HortScience, Alexandria, v. 16, n. 3, p. 310-312, 1981.

ZLENKO, V. A.; TROSHIN, L. P.; KOTIKOV, I. V. An optimized medium for clonal micropropagation of grapevine. Vitis, [S.1.], v. 34, n. 2, p. 125-126, 1995. 